\title{
High Unemployment Records of Graduated Students in the Development of Urban Agriculture in the Gaza Strip
}

\author{
Husam Al-Najar ${ }^{1 *}$, Hadi Khalil ${ }^{1}$, Yuni Sri Rahayu ${ }^{2}$ \\ ${ }^{1}$ Faculty of Science, Disaster Management Master Program. The Islamic University of Gaza, P.O. Box 108 Gaza \\ Strip, Palestine. \\ ${ }^{2}$ Biology Department, Faculty of Mathematic and Sciences, Universitas Negeri Surabaya. Indonesia. \\ Correspondence: E-mail: halnajar@iugaza.edu.ps
}

\section{A BSTRACT}

Urban agriculture plays a significant role in national development by contributing towards food security, job creation, and income generation. This study aims to assess the effect of unemployment records in graduated students in the recovery of the agricultural sector and the input to food security. A combination of both quantitative and qualitative research methods was employed in this study. In the quantitative design, 129 randomly selected urban farmers, completed the self-administered close-ended questionnaires, whereas the statistical analysis presents the socio-demographic, economic, and other aspects of the households. Based on the study result, around 2500 students graduated annually from 29 high educational institutes in Gaza Strip. The unemployment rate is around $41 \%$, therefore the graduated students found that urban agriculture is contributing to create more jobs opportunities and improving household income. The analysis showed that $18 \%$ of the urban farmers are illiterate, $31 \%$ passed primary education, $25 \%$ passed secondary education, and $26 \%$ are holding university degrees in different fields. It is highly recommend to include urban agriculture in the future plans of the ministry of labours, ministry of agriculture, and all relevant institutions to overcome the high unemployment records and to alleviate poverty in Gaza.
ARTICLE INFO

Article History:

Submitted/Received 24 Oct 2018

First revised 22 Jan 2019

Accepted 22 May 2019

First available online 24 May 2019

Publication date 01 Sep 2019

Keywords:

Gaza Strip,

Graduated students,

Urban agriculture,

Unemployment. 


\section{INTRODUCTION}

Gaza Strip is a small stretch of land bordering the Mediterranean Sea. The size of Gaza is $365 \mathrm{~km}^{2}$ (46 km in length and 6-10 km in width). The population has increased dramatically over the last 60 years: from about 50,000 in 1948 to an estimated 2 million today, making Gaza to be one of the most highly populated areas in the world (Yolsal-Çevikbilen and Taymaz, 2012). However, it was found by the Gaza Food Security Cluster report in 2015 that most households defined as food insecure, approximately 47\%, in Gaza experience chronic food insecurity. This is a sign of a long-term food crises and a depletion of coping mechanisms and resilience if it is kept away from a proper solutions and interventions.

Agriculture can generate incomes and create more jobs, can improve food security status, and contribute to poverty alleviation. In Gaza Strip, agriculture has gone through phases of expansion and land reduction. The cultivated area increased from 170 to 198 $\mathrm{km}^{2}$ from 1966 to 1968 . The cultivated area was reduced to $179 \mathrm{~km}^{2}$ in 1978; also the forest areas and sand dunes were reduced from $32 \%$ to $22 \%$ mainly due to the increase in urban areas, or in other words, due to the urbanization expanding (Biradar, 2009).

In fact, agriculture in Gaza experiences critical problems. Increasing pressure on land and water limit the capacity today, and even more the potentials of the sector tomorrow. Furthermore, the community is confronted with a lack of significant alternative employment and export potentials in the other economic sectors. This awareness and the recognition of the gravity of the situation led to look for alternatives to gain minor improvements. Thus, urban agriculture has come to be seen as incorporating important potentials for the future of Gazan agriculture (Nachmani, 1997).
The price of fresh fruits and vegetables are very expensive in Gaza Strip, given that the lands available for horticulture is very limited and with the on-going blocked and restrictions on land accessibility in place. At the same time, the population continues to grow at over $3 \%$ annually; putting additional pressure on the resources in one of the most densely inhabited areas of the world. Meanwhile, the very high level of urbanization in Gaza made the lands available for cultivations in Gaza very limited (Costello, 2009).

The production of urban farming can be defined as a "crisis induced strategy" under such economic circumstances, ensuring survival of the poorer segment of the population. Jakarta, the Capital of Indonesia, can be considered as an example in the recent history that its people managed to create a survival strategy during periods of economic decline and civil unrest in densely populated cities. In 1997, millions of people were vulnerable to food insecurity in Indonesia due to the economic disturbance, as they were left without enough money to buy sufficient food (Clover, 2003). In response to this, people engaged in urban agriculture and started producing food on small and vacant fields all over the city, even the former public parks were transformed into gardens, while government officials encouraged the people of Jakarta to grow their own food.

Household income, total expenses, food consumption, share of total expenditure on food, calorie consumption, and the status of nutritional are also important measures to the food security status of a household (Wolfe and Frongillo, 2001). Similar situation in Gaza Strip, socioeconomically crisis and high unemployment records lead to invest in urban agriculture. Based on our previous study (Al-Najar and El Hamarneh, 2019), therefore the main aim of this research is investigate the socio-cultural conditions and 
job opportunities could be saved by implementing appropriate urban agriculture concepts.

\section{MATERIALS AND METHODS}

In this study, we exploited both primary and secondary sources of data to collect the necessary and appropriate data. Thus, a combination of qualitative and quantitative data has been used as an input for the evaluation of the role of urban agriculture on food security. In light of this, interview and survey questionnaire have been used as the primary data gathering tools. The secondary sources include the use of journals, books, statistics and web pages.

Survey questionnaires have been administered to a sample of individual producers to gather the necessary quantitative information required for assessing the contributions of urban agriculture in reducing urban food insecurity at the household level.

Then the data has been analyzed using the statistical package for the social sciences (SPSS Ver. 20). This software is typically used in understanding social science analysis (Haristiani et al., 2017). Descriptive statistics, cross tabulations, including frequency counts, percentages, and other relevant data analyses presentation forms have been utilized in the study.

\section{RESULTS AND DISCUSSION}

\subsection{Level of Education of the Respondents}

Around $85.3 \%$ of the respondents "farmers" are males, while $14.7 \%$ of them are females. It is clearly shown that percentage of men is much higher than the women's as it is not easy to reach out to the women in Gaza households due to religious and cultural considerations. Furthermore, men are responsible for the management of the filed works like seeding, tillage, irrigation, application of fertilizers and pesticides. While the work of the women limited to the harvest of the product and in many cases selling in the market. Therefore, in the peasant society, personal contacts and external relations are the men responsibility.

Moreover, about $1 \%$ of the farmers are under the age of 20 years, $27.1 \%$ are from 21 30 years, $34.1 \%$ are from "31-40" years, and $38 \%$ of them are aged more than 41 years. It is concluded that the percent of youth amongst the respondents is a relatively high, because Urban Agriculture can be considered as a main source of income.

The percentage of 0-17 years accounted for $48 \%$ in Gaza Strip, and the percentage of 18-29 years accounted for $23.2 \%$ while the age of 60 years and over accounted for $4.3 \%$ of the total population of Gaza Strip.

Concerning the level of education, as shown in Figure 1, 17.8\% of the urban farmers are illiterate, $31 \%$ passed primary education, $24.8 \%$ passed Secondary education, and $26.4 \%$ hold university degrees in different fields (Figure 1).

The educational level of the urban agriculture practitioners targeted in this study considerably varies from the one that is illiterate to the level of university graduate. The $26.4 \%$ of farmers who hold university degree explain to some extend the unemployment records in the field of their specialization in the different field such as education, industry and construction engineering. This situation demonstrates people from different background of life are involved in urban agriculture using it either as a major source of livelihood, or additional source of livelihood or the adaptive or coping strategy. 


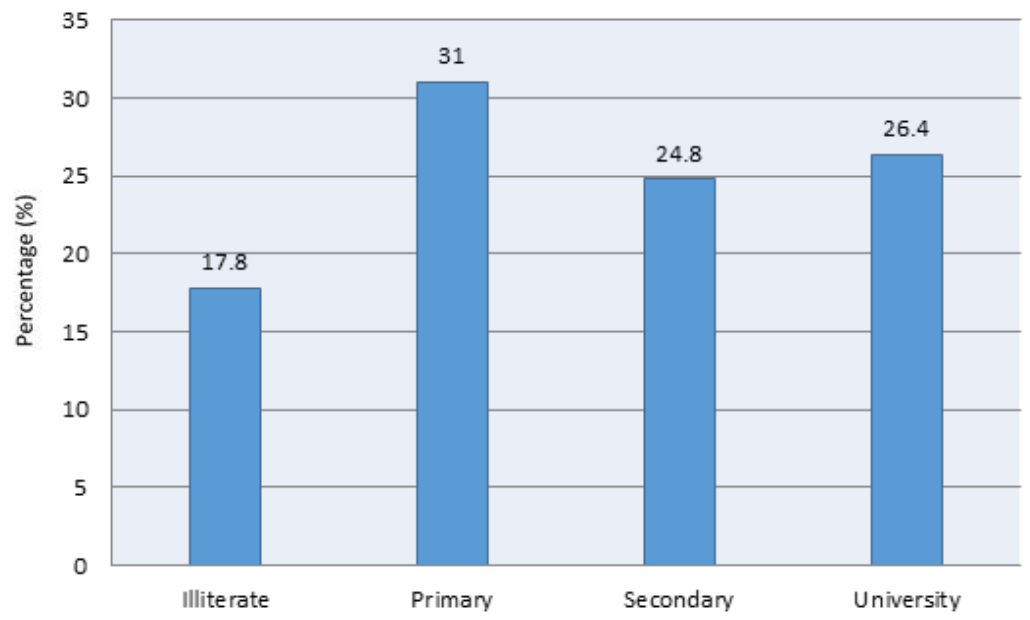

Figure 1. Level of education for the respondents.

Illiteracy is more prevalent among females than males since there were $3.4 \%$ of the total number of Palestinian males aged 15 years and over and $9.5 \%$ of the total number of Palestinian females of the same age group. The highest concentration of illiteracy was at rural areas $20.6 \%$ followed by refugee camps $6.9 \%$ and urban areas $6.1 \%$.

For the uneducated farmers, reportedly they immerse in the Urban Agriculture as it is not easy for them to get another opportunities in the different sectors in Gaza strip due to present economic hardships and the high rate of unemployment. According to the ILO report 1972, to be uneducated young is the worst of all possible circumstances from the point of view of seeking work.

In literature regarding the relation between the education and food security, they found that hunger is highly correlated with the illiterate people (Rosegrant and Cline, 2003). In the research case study, only $17.8 \%$ of the respondents have no formal education while most of the respondents received some form of education which implies that the level of food security in the case study should be relatively high. However, the level of food insecurity in Gaza strip is still high as the education does not protect the people from the impact of economic crisis that Gaza experience since many years. Mutisya et al. (2016) stated that investment in the education of the slum households may, in the long term, contribute to reduction in the prevalence of food insecurity. The probability of being food insecure decreased by 0.019 for a unit increase in the average years of schooling for a given household. The effect of education, remained significant even after controlling for household wealth index, a more proximate determinant of food security in a cash-based economy such as the urban slums.

In the study area, it was noted from the survey that the non-educated urban farmers were hesitated while completing the questionnaire. This can be considered a big challenge for those researchers who use questionnaires for their study as it may effect on the credibility of the study.

\subsection{Monthly Income of the Respondents}

The data analysis shows that the monthly income urban farmers ranges from 30-700 USD per month with a mean of 200 USD, median of 150 USD, and standard deviation of 170 USD. The income believed to be much more of what the respondents reported, as they focus on cash and export crops which make large income. However, while performing the survey, it was noted that the urban farmers were behaving in a way to draw the attention and the sympathy 
of the INGOs/NGOs seeking for more support and more benefits form the fund donations. According to Zhou, et al. (2019), the income status of the household influences the level of food security, while the poverty, which decreases purchasing power at the household level, is considered as a main factor to food insecurity. Premanandh (2011) stated that The global food situation is redefined by many driving forces such as population growth, availability of arable lands, water resources, climate change and food availability, accessibility and loss. The combined effect of these factors has undeniably impacted global food production and security.

Since the International poverty line varies between 1.25 and 2.50 USD per person per day (the poverty line in Palestine is 1.8 USD, the majority of the urban agriculture practitioners in the area of the study are not suffering from poverty, taking into consideration that approximately $39 \%$ of Gaza people are suffering from poverty. Noticeably, farmers did not pay for water as an asset, but only pay for the operation of pumping (Al-Najar, 2011). Thus, the low farms input cost makes them profitable and explains the sensible income of the urban farmers, and therefore the household food security status sounds good. However, water security is questionable in the long run if the current practice is continued, due to the very high consumption of irrigated water for the crops which are cultivated in green-houses, particularly strawberry which consume more than $1150 \mathrm{~m}^{3} /$ dunam/year.

\subsection{Main reason for respondents to start urban agriculture}

As shown in Figure 2, the unemployment was ranked as the first reason for the respondents to start urban agriculture with $63 \%$ in the area of the study. It is clearly shown that the respondents aim to have job opportunities by practicing urban agriculture to improve their income and therefore the food security will be improved.

Low income was ranked as the second reason with $59.1 \%$. It is also noted that the household low food supply plays in important role to motivate the respondents to start urban agriculture with $52.8 \%$ in the area of survey. However, only $15.7 \%$ started the urban agriculture to obtain safer food. Also, the key informant responses to the interview question on the reason to engage in urban agriculture reveals that the households are practicing urban agriculture due to unemployment problems and low income.

The urban farmers behavior agree with study conducted by Al-Najar (2014), where Urban agriculture development started after the siege imposed on the Gaza Strip in 2007 where many families lost their work opportunities in the city. Beside the return of farmers to their land which had created seasonal jobs, the government in Gaza Strip also offers the state-owned for farmers to enhance the agricultural sector and therefore to minimize the unemployment records. 


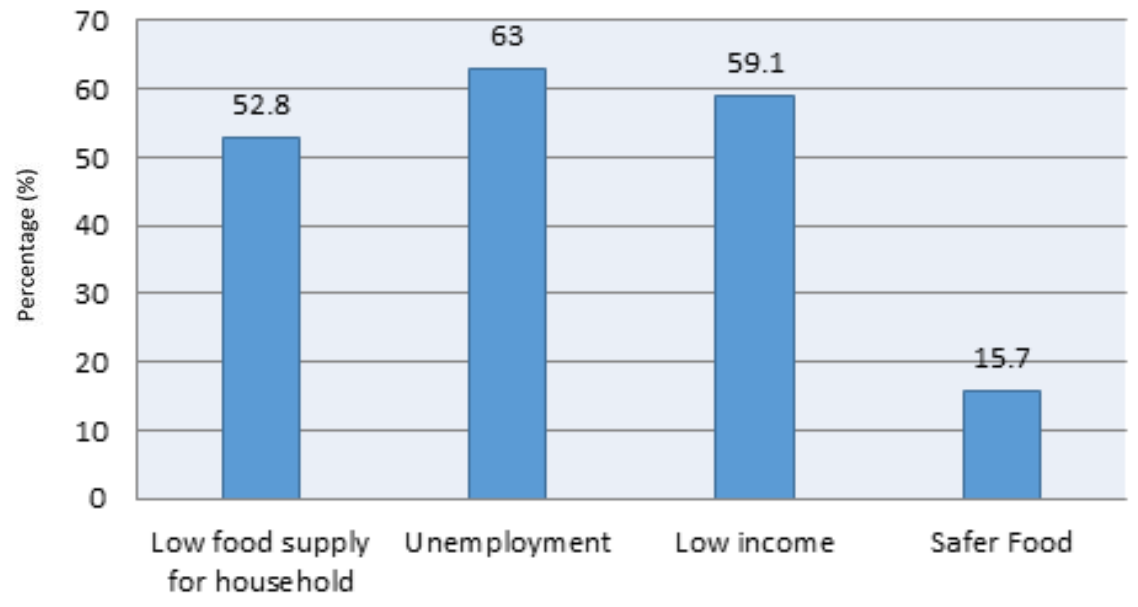

Figure 2. The respondents' reason to start urban agriculture.

This result compatibles with the result of the study of Zezza and Tasciotti (2010); when reveals that urban agriculture can be a main or a secondary source of income, can directly provide access to large number of nutritionally rich foods at the household level (fruit, vegetable, meat) and can improve the of household food consumption stability.

Finally, it was also found that education level is a major factor that encourages involvement in urban agriculture as $82.2 \%$ of the respondents received some form of education while only $17.8 \%$ of the respondents have no formal education. $26.4 \%$ of the educated urban farmers have university degrees, but due to the high level of unemployment given the bad economic situation, they were forced to engage in urban agriculture as their source of income.

A good indicator of household food security level, the average daily income of the urban farmers was acceptable to some extent as it was above the poverty line. Monthly income for them ranges from 30 to 700 USD, with a mean of 170 USD.

One of the major findings of the study is the revelation that those who are engaged in urban agriculture started due to one or more of the following: low food supply at the household level (52.8\%), low income (59.1\%), unemployment (63\%), and low food safety for foods available to their household (15.7\%). Based on Rezai et al. (2014) that food security can be derived from urban agriculture since it provides sufficient quantities of food, appropriate nutrition, cost-effective food supplies and reduction in food bills.

\section{CONCLUSION}

Around 2500 students graduated annually from 29 high educational institute in the Gaza Strip. The unemployment is around $42 \%$, therefore the graduated students found that urban agriculture is contributing to create more jobs opportunities and improving household income. It is highly recommend to include urban agriculture in the future plans of the ministry of labours, ministry of agriculture and all relevant institutions to overcome the high unemployment records and to alleviate poverty in the Gaza vulnerable economy.

\section{AUTHORS' NOTE}

The authors declares that there is no conflict of interest regarding the publication of this article. Authors confirmed that the data and the paper are free of plagiarism. 


\section{REFERENCES}

Al-Najar, H. (2011). The integration of FAO-CropWat model and GIS techniques for estimating irrigation water requirement and its application in the Gaza Strip. Natural Resources, 2(3), 146.

Al-Najar, H. (2014). The effect of urban agriculture on domestic water supply system in the semi-urban areas. The 5th International Conference on Engineering and Sustainability (ICES5). The Islamic University of Gaza. Gaza Strip, Palestine.

Al-Najar, H., and El Hamarneh, B. (2019) The Effect of Education Level on Accepting The Reuse of Treated Effluent in Irrigation. Indonesian Journal of Science and Technology, 4(1), 28-38.

Biradar, C. M., Thenkabail, P. S., Noojipady, P., Li, Y., Dheeravath, V., Turral, H., and Xiao, X. (2009). A global map of rainfed cropland areas (GMRCA) at the end of last millennium using remote sensing. International Journal of Applied Earth Observation and Geoinformation, 11(2), 114-129.

Clover, J. (2003). Food security in sub-Saharan Africa. African Security Studies, 12(1), 5-15.

Costello, A., Abbas, M., Allen, A., Ball, S., Bell, S., Bellamy, R., and Lee, M. (2009). Managing the health effects of climate change: lancet and University College London Institute for Global Health Commission. The Lancet, 373(9676), 1693-1733.

Haristiani, N., Aryanti, T., Nandiyanto, A. B. D., and Sofiani, D. (2017). Myths, Islamic View, and Science Concepts: The Constructed Education and Knowledge of Solar Eclipse in Indonesia. Journal of Turkish Science Education, 14(4), 35-47.

Mutisya, M., Ngware, M. W., Kabiru, C. W., \& Kandala, N. B. (2016). The effect of education on household food security in two informal urban settlements in Kenya: a longitudinal analysis. Food Security, 8(4), 743-756.

Nachmani, A. (1997). Water jitters in the Middle East. Studies in conflict \& terrorism, 20(1), 67-93.

Premanandh, J. (2011). Factors affecting food security and contribution of modern technologies in food sustainability. Journal of the Science of Food and Agriculture, 91(15), 2707-2714.

Rezai, G., Shamsudin, M. N., and Mohamed, Z. (2016). Urban Agriculture: A Way Forward to Food and Nutrition Security in Malaysia. Procedia - Social and Behavioral Sciences, 216, $39-45$.

Rosegrant, M. W., and Cline, S. A. (2003). Global food security: challenges and policies. Science, 302(5652), 1917-1919.

Wolfe, W. S., \& Frongillo, E. A. (2001). Building household food-security measurement tools from the ground up. Food and Nutrition Bulletin, 22(1), 5-12. 
203 | Indonesian Journal of Science \& Technology, Volume 4 Issue 2, September 2019 page 196-203

Yolsal-Çevikbilen, S., and Taymaz, T. (2012). Earthquake source parameters along the Hellenic subduction zone and numerical simulations of historical tsunamis in the Eastern Mediterranean. Tectonophysics, 536, 61-100.

Zezza, A., and Tasciotti, L. (2010). Urban agriculture, poverty, and food security: Empirical evidence from a sample of developing countries. Food policy, 35(4), 265-273.

Zhou, D., Shah, T., Ali, S., Ahmad, W., Din, I. U., and Ilyas, A. (2019). Factors affecting household food security in rural northern hinterland of Pakistan. Journal of the Saudi Society of Agricultural Sciences, 18(2), 201-210. 